\title{
ASSESSMENT OF FOOD SECURITY STATUS OF FADAMA III PROJECT BENEFICIARIES IN SAKI AGRICULTURAL ZONE OF OYO STATE, NIGERIA
}

\author{
SANUSI, Wasiu Adekunle \\ Department of Agricultural Economics, Ladoke Akintola University of Technology Ogbomoso \\ http://doi.org/10.35410/IJAEB.2019.172182
}

\begin{abstract}
The study investigated the household food security situation among Fadama III project beneficiaries in Saki Agricultural development zone of Oyo State, Nigeria. Data were collected through interview scheduled from 166 farm households randomly selected. Data were analyzed by employing descriptive statistics, Logit regression analysis, food security status was determined using mean per capita expenditure. The result of the analysis revealed that most household head $(65.06 \%)$ were male, $76.51 \%$ were married with average household size of seven. Most of the respondents have high years of farming experience and had basic or elementary education. The findings of the study further revealed that food insecurity incidence was 0.32 , the depth or gap was 0.06 and the food insecurity severity stood at 0.02 . This indicated that significant beneficiaries of Fadama III programme are still living below the food insecurity line. Also, household size $(t=-6.63)$, education $(t=-2.48)$, access to credit $(t=-1.86)$, farm size $(\mathrm{t}=-1.77)$ and Off-farm income $(\mathrm{t}=-1.77)$ significantly predicted food insecurity status of Fadama III beneficiaries in the study area. However, this study recommended that farming household should be sensitized more on the economic benefit of diversifying farm enterprises and stakeholder should ensure availability of more credit facilities to Fadama beneficiaries in the study area.
\end{abstract}

Keywords: Assessment, Fadama, Food security, Rural - Households, Analysis.

\section{INTRODUCTION}

Then eglect of the agricultural sector as a result of the total dependency of the economy on the oil sector and the rising population sufficient food production becomes problematic. These shortage in food production had continually reduced to the extent that most of Nigerians now have no access to quantity and variety of food needed for healthy living and are living below poverty line i.e less than one US dollar a day, (Oriola, 2009).

The consequence of thedepletionoflabourforcerequiredforagriculturalsectortoplayitsrolesof providing food for the teaming population of Nigeria and providing raw materials to feed the country's dwindlingagro-industries among others. Asa resultofthis,foodinsecurityemergedandtheagro-industriesinboththe ruralandurbancentreswereunabletosustainproduction. Thishasreduced in no small measure the 
output of food per capita, thus making Nigeria the least in the sub-Saharan Africa. There is the reform the threat of hunger and poverty as $70 \%$ ofthepopulationlivesonlessthan $\$ 100$ (US\$0.7)perday and youth unemployment is very high(Oni,2008).

Past government has implement programmes and policies in Nigeria that focused on improving living standards of Nigerians, but most of these programmes have found it difficult to stem growth of rural poverty especially among farmers (Ezeh, 2007). This might be as a result of non-inclusiveness of the targeted audience in the programme design. Fadamaprogramme is one such programme that has today become a household name among farmers and state governments across the country (Salawu, 2011).Agriculture especially, Small-scale irrigation "Fadama" plays a key role in the economics of Nigeria as a basic source of food, income, and employment, especially for women in the "slack" period of rain-fed agriculture (Ogunjimi, et al.,2002).Fadama, is Hausa word meaning, the seasonally flooded or flood able plains along major savannah rivers and or depressions adjacent to seasonally or perennially flowing streams and rivers. Fadama as a programme involves development of flood plains and lying areas underlined by shallow aquifers found along Nigeria's Rivers systems (Ezeh, 2007; Ingawa, et al., 2004; Nwachukwu, 2006).

The National Fadama Development Project (NFDP) was established to guarantee all-year round growing of crops and promotion of simple and low cost improved irrigation under a World Bank financing. Food crops grown on the Fadama include rice, leafy vegetables, okra and maize to mention but a few. Fadama projects aim at reducing poverty and increasing farm productivity and income of farmer participants (Bello, 2008).

Olorunfemi, (2013) posited thatfood prices continue to soar up day by day, and, ultimately going out of the reach of the common man while household incomes in the country are significantly debased by the staggering inflation rate. The retail price index for food in 1970 was $12.5 \%$ but this has risen outrageously to $548.2 \%$ in 2005 . This underscores the fact that households' income can hardly cope with soaring food prices, which has compelled increased food spending out of households' income of between 60 percent and 80 percent coupled with poor income per capita, in Nigeria.

Food insecurity, a situation that exists when people lack secure access to sufficient amounts of safe and nutritious food for normal growth and development and an active and healthy life. It may be caused by the unavailability of food, insufficient purchasing power, inappropriate distribution or inadequate use of food at the household level. Food insecurity, poor conditions of health and sanitation and inappropriate care and feeding practices are the major causes of poor nutritional status, (Afri-Dev-info, 2014).

A school of thought for instance believes that there is enough domestic production of food in Nigeria and that the problem with food security lies in poor storage marketing and distribution arrangement which greatly reduce available market supplies of food (Omonona et al., 2008). Unlike other commodities the demand for food will increase as they are essential for human survival. 
People at lower income levels want to satisfy their physiological needs for food based on the preference of their culture. As consumer gain affluence, their attention turns to the quality of food they eat. People then demand food that are safe or that promote good health and become more concern about food safety, like pathogens and disease risks (Senauer, 2001).

In the work of Odusina et al., (2014), they studied seasonal assessment of household food access in Ibadan metropolis, Nigeria. Data were collected from a hundred and eighty households interviewed both during the harvest and hunger period. The data obtain were analysed using Food Insecurity Access Scale (HFIAS) and z-test. It appeared that the average households tend to have significantly better food access during the harvest period than in the hunger period. The finding also posits that households in Ibadan metropolis had a higher mean score of dietary diversity in the harvest period than in the hunger period.

Bedeke, (2012) studied factors influencing rural households' food in security status in Kersadistrict, East Hararghe Ethiopia and find out the copingstrategies. One hundred and twenty (120)house hold heads weres elected from three Peasant Associations in the districtusing probability to proportion size stratified random sampling technique. A survey was conducted to collect the primary data from sample respondents and supplemented by secondary data. Abinarylogisticregression model was fitted to analyze the potential variables affecting house hold food in security in the study area.

In the recent release of Afri-Dev- info, (2014), Nigeria was ranked third in Africa with highest proportion of people in the state of undernourishment/ hunger, and more than 12 millions Nigerians were suffering from this. NBS, (2012) reported that food poverty in Nigeria stood at 41 per cent, meaning that about 41 per cent of Nigerians were food insecure, while both absolute and relative food poverty stood at 60.9 per cent. It should be noted as Markomac, (2006) submitted that the demand for food will never decrease as they are essential for human survival, therefore with increased emphasis on how to balance food supply and demand so as to reduce consequences of food insecurity on the people in Nigeria, there is the urgent need to carry out more research on food insecurity. Therefore, this study analyse the determinants of food insecurity among Fadama III project beneficiaries in Saki Agricultural zone of Oyo State Nigeria.

\section{METHODOLOGY}

The study was carried out in Saki Agricultural Development (ADP) zone of Oyo State, Multistage sampling procedure was used to select sample for the study. Saki ADP comprises of nine local government area, about one-third of the LGAs was purposively selected in the first stage, the second stage involve the random selection of five villages each from the selected LGA and the last stage was involve the proportionate selection of the respondents for the study. A total of 180 respondents were selected and interviewed. The study employed descriptive statistics, Foster, Greer and Thorbecke (FGT), and Logit regression model to analysed the data obtained.

\section{Food Insecurity}


Households' expenditure on food which has found wider application in several empirical studies [Foster et. al., (1984); Omonona et al., (2007) Olaolu et al., (2013) and Ibok, et al., (2014)] were used to estimate the food insecurity line for Fadama III beneficiaries in Shaki Agricultural zone of Oyo State, Nigeria. The food insecurity index $\left(Z_{i}\right)$ used to classify household's food insecurity status is given by:

$\mathrm{Zi}=\frac{\text { percapitafoodexpenditureforith household }}{\frac{2}{3} \text { meanpercapitafoodexpenditureofallhouseholds } \ldots . . . . . . . . . . . .}$

Where $Z_{i}=$ food insecurity index (when $Z_{i} \geq 1=$ food secure ith household, $Z_{i} \leq 1=$ food insecure ith household). Households were then classified into their food security status as food insecure and food secure households based on the food insecurity line. A food insecure household is that whose per-capita monthly food expenditure falls below two-thirds of the mean monthly per-capita food expenditure while a food secure household is that whose per-capita monthly food expenditure is above or is equal to two-thirds of the mean per-capita food expenditure.

Additionally, food insecurity gap index, food surplus gap index and the headcount ratio of food security were calculated for the sample households based on the food insecurity index (Z). Setting $\alpha$ equal to zero, $F_{0}$ is the head count index measuring the incidence of food insecurity. That is, the proportion of food insecure people from the total population. The food insecurity gap (P), measures the extent to which food insecure households on average fall below the food insecurity line and the food surplus gap (S), the extent by which food secure households exceeded the food insecurity line.

Adopting the method of estimation of the Foster, Greer and Thorbecke (1984) poverty index, the food security index was estimated as:

$\mathrm{F} \alpha=\frac{1}{M} \sum_{i=1}^{m}\left(\frac{R-y i}{R}\right)^{\sigma}$

Where:

$\mathrm{F} \alpha=$ Food insecurity index $(\alpha=0,1$ and 2$)$

$\mathrm{R}=$ Food insecurity line (2/3 mean per-capita food expenditure)

$\mathrm{M}=$ number of households below the food insecurity line (food insecure).

yi $=$ per capita food expenditure in increasing order for all households

$\alpha=$ is the aversion parameter that takes values of zero, one or two.

$\mathrm{n}=$ total number of household in the sample

\section{Logit Regression Analysis}

This is a statistical method for analyzing a data set in which there are one or more independent variables that determine an outcome. The outcome is measured with a dichotomous variable (in which there are only two possible outcomes). Following Menard (1995), and Agresti (1996), the study logistic model is specified as

$P=E(Y i=1 / X i)=e\left(\beta_{0}+\beta_{1} X_{1}+\beta_{2} X_{2} \ldots \ldots . . \beta_{i} X_{i}\right)$ 
Where $\mathrm{Pi}$ is a probability that dependent variable $Y_{i}=1$ food insecure and $Y_{i}=0$ otherwise. $\beta_{0}$ is the intercept which is constant, $\beta_{1}$ is the coefficient of the factors that determines food insecurity among Fadama III project beneficiaries in the study area. $X_{i}$ is a set of independent factors/variables. The factors hypothesized include:

$\mathrm{Yi}=$ Food insecurity status (food insecure $=1$, otherwise $=0$ )

$\mathrm{X}_{1}=$ Age of household head (years)

$\mathrm{X}_{2}=$ Gender

$\mathrm{X}_{3}=$ Education $($ years $)$

$\mathrm{X}_{4}=$ Household size (number)

$\mathrm{X}_{5}=$ Access to credit $(1=$ Yes, $0=$ No $)$

$\mathrm{X}_{6}=$ Farming experience (years)

$\mathrm{X}_{7}=$ Farm Association (Yes 1, Otherwise 0)

$\mathrm{X}_{8}=$ Farm size (hectares)

$\mathrm{X}_{9}=$ Primary occupation(Farming $=1$, Otherwise 0 )

$\mathrm{X}_{10}=$ Off-farm income (Naira)

$\mathrm{E}=$ Error term

\section{RESULTS AND DISCUSSION}

Table 1 shows that most $(34.94 \%)$ of the respondents in the study area were between the age range of 41-50 years followed by age range 31-40 years with $33.13 \%, 18.68 \%$ of the respondents were between the ages of 51-60 years, while less than 30 years was8.43\%. The mean age was 49.3. This implies thatmost of the respondents are in their active age. The table also showed that majority of the respondents weremale with a percentage of $65.06 \%$, while the female Fadama III beneficiarieswere $34.94 \%$. About $61 \%$ of the respondents had household size between 6-10 members, $33.73 \%$ of the respondents had household size not more than 5 members, while $4.82 \%$ had a household size of more than 10 members.

Also, the table showed that $76.51 \%$ of the respondents were married, $4.82 \%$ were single, while $16.26 \%$ are widowed. The high percentage of married respondents implies that most of the Fadama III farmers were married. About 53\% had primary education, 31.93\% had secondary education and $7.23 \%$ of the respondents had no formal education. Thisindicatedthat majority of the respondents are literates, as least they can read and write. Also, $71.69 \%$ of the respondents hadnot more than 10 years of farming experience, $10.8 \%$ had farming experience between 11-20 years, while $7.83 \%$ and $3.61 \%$ had farming experience between 21-30 years and more than 30 years farming experience with an estimated mean of 24.27 years. This implies that majority of the farmers are highly experience

The table also revealed that $98.80 \%$ of the respondents have farm size not more than 5 hectares of land, $1.20 \%$ had farm size within the range of 6-10 hectares. About $95 \%$ of the respondents are visited by the extension agents, which $4.82 \%$ of the respondents received no visit from extension office. This show that most of the respondents have support and assistance which may increase production and it will also bring about fast improvements in agriculture generally. 
International Journal of Agriculture, Environment and Bioresearch

Vol. 4, No. 03; 2019

ISSN: $2456-8643$

\begin{tabular}{|c|c|c|}
\hline Socioeconomic variables & Frequency & Percentage \\
\hline \multicolumn{3}{|l|}{ Age } \\
\hline$\leq 30$ & 14 & 8.43 \\
\hline $31-40$ & 55 & 33.13 \\
\hline $41-50$ & 58 & 34.94 \\
\hline $51-60$ & 31 & 18.68 \\
\hline Above 60 & 8 & 4.82 \\
\hline \multicolumn{3}{|l|}{ Mean $=49.3$} \\
\hline \multicolumn{3}{|l|}{ Gender } \\
\hline Male & 108 & 65.06 \\
\hline Female & 58 & 34.94 \\
\hline \multicolumn{3}{|l|}{ Marital status } \\
\hline Single & 8 & 4.82 \\
\hline Married & 127 & 76.51 \\
\hline Widow & 27 & 16.26 \\
\hline Divorce & 3 & 1.81 \\
\hline Separated & 1 & 0.60 \\
\hline \multicolumn{3}{|l|}{ Household size } \\
\hline$\leq 5$ & 56 & 33.73 \\
\hline $6-10$ & 102 & 61.45 \\
\hline Above 10 & 8 & 4.82 \\
\hline \multicolumn{3}{|l|}{ Mean $=7.13$} \\
\hline \multicolumn{3}{|l|}{ Education status } \\
\hline No formal education & 12 & 7.23 \\
\hline Primary education & 88 & 53.01 \\
\hline
\end{tabular}




\begin{tabular}{|l|l|l|}
\hline Secondary education & 53 & 31.93 \\
\hline Adult education & 2 & 1.20 \\
\hline Quranic education & 11 & 6.63 \\
\hline Farm size(Hectares) & & \\
\hline$\leq 5$ & 164 & 98.80 \\
\hline $6-10$ & 02 & 1.20 \\
\hline Mean = 1.38 & & \\
\hline Farming experience & & \\
\hline$\leq 10$ & 119 & 71.69 \\
\hline $11-20$ & 28 & 16.87 \\
\hline $21-30$ & 13 & 7.83 \\
\hline Above 30 & 6 & 3.61 \\
\hline Mean $=21.42$ & & \\
\hline Extension visit & & 4.82 \\
\hline Yes & 158 & $\mathbf{1 0 0 . 0 0}$ \\
\hline No & 8 & \\
\hline Total & $\mathbf{1 6 6}$ & 95.18 \\
\hline
\end{tabular}

\section{Source: Field Survey, 2017}

\section{Analysis of Food Insecurity Status of the Respondents using FGT Food Security Index}

The degree of food insecurity was assessed using the three insecurity indices: Headcount ratio or food insecurity incidence $\left(\mathrm{F}_{0}\right)$, depth or gap of food insecurity $\left(\mathrm{F}_{1}\right)$, food insecurity severity or intensity $\left(\mathrm{F}_{2}\right)$, following the Foster, Greer and Thorbecke (FGT, 1984) poverty measure. This is reflected in the degree to which the per capita food expenditure of the household or individuals falls below the food security line. The total per capita food expenditure for the 166 respondents was $\$ 2,552,547.1$ and the mean per capita food expenditure were $\$ 15,376.79$.The food insecurity line was computed as $2 / 3$ of the mean per capita food expenditure of the household, which is $\$ 10,251.19$. However, any household's per capita expenditure below the amount in the food security line was described as being food insecure, while those households whose per capita expenditure above or equaled amount in the food insecurity line is described as food secure. 
Therefore, with a food security line of $\$ 10,251.19$, the head-count ratio or food insecurity incidence $\left(\mathrm{F}_{0}\right)$ were 0.32 . This implies that $32 \%$ of the respondents in the study area were below the food security line and were relatively poor. The food insecurity depth or gap $\left(\mathrm{F}_{1}\right)$ was 0.06 . This value indicated that $6 \%$ of the respondents were below the food security line and therefore required an improvement in their income to reach the food security line i.e. each food insecure households need about 8 percent of the caloric requirement level besides their per capita income. The food insecurity severity or intensity $\left(\mathrm{F}_{2}\right)$ was 0.02 . This value indicated that $2 \%$ of the respondents in the study were severely poor.

Table 3: Foster, Greer and Thorbecke Food Insecurity Status

\begin{tabular}{|l|l|l|}
\hline FGT parameters & Estimate & Percentage \\
\hline Incidence $\left(\mathrm{F}_{0}\right)$ & 0.32 & 32 \\
\hline Depth/gap $\left(\mathrm{F}_{1}\right)$ & 0.06 & 6 \\
\hline Severity $\left(\mathrm{F}_{2}\right)$ & 0.02 & 2 \\
\hline
\end{tabular}

\section{Source: Field Survey, 2017}

\section{Determinants of Food Insecurity using Logit regression model}

The empirical estimation of the logit analysis result as presented in table reveals a log likelihood function of 79.095, chi-square of 82.428. Table 4 showed the determinants of food insecurity among Fadama III beneficiaries in Shaki Agricultural zone of Oyo State. As shown on the table, the coefficient of education, household size, access to credit, farm size and off-farm income were negative and statistically significant determinants of food insecurity in the study area.

The coefficient of education was negative and significant $1 \%$ level; the result showed that an increase in education of the respondents will reduce the likelihood of being food insecure. Also, household size of the respondents was significant at $1 \%$ level and has a negative influence onfood insecurity. A unit increase in household size will lead to $2.7 \%$ decrease in the likelihood of being food insecure. This implied that the larger thehousehold sizes, the greater the likelihood of being food insecure.

Credit accessibility influences food poverty reduction. The result as presented on the table showed that a unit rise in the access to credit will reduce the probability of the respondents being food insecure by about 3\%. This indicated that the more the respondents access credit for production, the less their chance of becoming food insecure. The coefficient of farm size was also negative and significant at $10 \%$ level. The result indicated that increase in farm size of the respondents will reduce the chance of becoming food insecure. And lastly, off-farm income of the respondents was significant at $10 \%$ level and has a negative effect on the food insecurity 
level of the respondents. This implies that the higher the off-farm income the less food insecure the respondents and vice versa.

Table 4: Determinants of food insecurity among Fadama III project Beneficiaries

\begin{tabular}{|l|l|l|l|l|}
\hline Variables & Coefficient $(\mathrm{mfx})$ & Standard error & $\mathrm{t}$-value & Prob>t \\
\hline Age & 0.1198189 & 0.1609113 & 0.74 & 0.457 \\
\hline Gender & -0.0028692 & 0.0061454 & -0.47 & 0.641 \\
\hline Education & -0.3211595 & 0.1293593 & -2.48 & $0.014^{* * *}$ \\
\hline Household size & -0.0279032 & 0.0042158 & -6.62 & $0.000^{* * * *}$ \\
\hline Access to credit & -0.0292774 & 0.0157696 & -1.86 & $0.065^{*}$ \\
\hline Farming experience & 0.0008319 & 0.0008867 & 0.94 & 0.350 \\
\hline Farm association & 0.0755954 & 0.7356408 & 0.10 & 0.918 \\
\hline Farm size & -0.7260634 & 0.4094211 & -1.77 & $0.076^{*}$ \\
\hline Primary occupation & 0.0025683 & 0.0054835 & 0.47 & 0.640 \\
\hline Off-farm income & -0.0248387 & 0.0140698 & -1.77 & $0.080^{*}$ \\
\hline Constant & 0.1712841 & 0.0770992 & 2.22 & $0.026^{* *}$ \\
\hline Diagnostic test & & & & \\
\hline Chi-squared $=82.43$ & & & \\
\hline Log livelihood function $=70.095$ & & & \\
\hline Number of observation = 166 & & & \\
\hline
\end{tabular}

Source: Field Survey, 2017

\section{CONCLUSION}

The findings of the study showed that most of the respondents were young and in their productive age. Large number of the respondents was married with average household size of 7 members; this indicated that most of the respondents had a considerable household size. Also, the respondents were of experience in farming though they are smallholder farmers. The food insecurity incidence showed that significant number of the respondents was food insecure and 
this suggests that they were still living below the food insecurity line. Also, household size, education, access to credit, farm size and Off-farm income significantly predicted food insecurity status of Fadama III beneficiaries in the study area. However, this study recommended that farming household should be sensitized more on the economic benefit of diversifying farm enterprises and stakeholder should ensure availability of more credit facilities to Fadama beneficiaries in the study area.

\section{REFERENCES}

Afri-Dev-info, (2014). 2014 Africa food security and hunger/undernourishment and scorecard.

Scorecard Research, Analysis, and Design by Africa Health, Human and Social Development Information Service.

Agresti, (1996). The use of logistic model in analyzing the determinants of poverty among farmers in Nigeria. Current Research Journal of Social Sciences 2(5):81-87.

Bedeke, S.B (2012). Foodinsecurity andcopingstrategies:aperspectivefromKersa district,EastHarargheEthiopia. Journal of Food Science and Quality

Management.5: 19-26

Bello, A. (2008). Fadamaneeds. Instrument for millennium development goal: An Article written on Fadama II update in a bulletin of National Fadama Development Office. Abuja, Nigeria (PCU-NDDO). P.3.

Ezeh, C. I., (2007). Poverty Profiles and Determinants of Expenditures of Rural Women Households in Abia State, Nigeria". The Nigerian Journal of Development Studies. 6(6), $1-17$

Foster,J.E.,Greer, J.,andThorbecke, E.(1984).Aclassofdecomposablepovertymeasures, econometrica,52(3), 761-776.

Ibok, O. W., Bassey, N. E. Atairet E. A., and Obot, O. J. (2014). Food security determinants among urban food crop farming households in Cross river State, Nigeria. Asian Journal of Agricultural Extension, Economics and Sociology 3(1), 76-90

Ingawa, S.A., Oredipe,A.A.,Idefor, K., and Okafor,C. (2004). Facilitators project implementation manual. Second national Fadama development project (Fadama II). Federal ministry of Agric and Rural Devt. Abuja, Nigeria.

Markomac, K. (2006). Reappraisal of nutrition indices and measurement of children in Anambra State. Oxford Press

National Bureau of Statistics (NBS,2012). Nigeria Poverty Profile 2010. Federal Government of Nigeria. Pp23

Nwachukwu, I.N. (2006). Efficiency of vegetable production in Imo State; The case of fadama Teifairia occidentalis. M.Sc. Thesis. Department of Agricultural Economics, Michael Okpara University of Agriculture Umudike, Abia State, Nigeria.1-5

Ogunjimi, L.A.O., and Adekalu, K.O. (2002). Constraints of Small Irrigation (Fadama) in Nigeria. Food Review International. 8(4), 295 - 304

Oni, K.C. (2008). Transforming agricultural potentials to wealth in Northern Nigeria. Invited paper presentedattheNorthern Nigerian economicandinvestmentsummit(NEIS), Abuja,October,2008.

Omonona, B. T., Agoi, A., and Adetokunbo, G (2007). Analysis of food security situations among Nigerian urban households: Evidence from Lagos State. Journal of Central 
European Agriculture8(3),397-400.

Odusina, O.A., Afolami, C.A., and Momoh, S., (2014). Seasonal assessment of household food access in Ibadan metropolis, Nigeria. Discourse Journal of Agriculture and Food Sciences. 2(3), 53-58.

Olaolu, M.O., Akinnagbe, O. M., and Agber, T. (2013). Impact of national fadama development project phase (II) on poverty and food security among rice farming beneficiaries in Kogi State, Nigeria. American Journal of Research Communication. 1(10), 280-295

Olorunfemi, S., (2013). Demand for food in Ondo State, Nigeria: Using Quadratic almost ideal demand system. E3 Journal of Business Management and Economics. 4(1):001-019

Oriola,E.O.(2009).Irrigationagriculture. Anoption forachieving themillenniumdevelopment goals (MDGs)inNigeria.JournalofGeographyandregional planning.2(7), 176-181

Salawu, R. (2011). The problem with Fadama III project" Nigerian Tribune. Available at www. Sail rdaytribiinc .com .11 g. Accessed 14th July, 2012. 